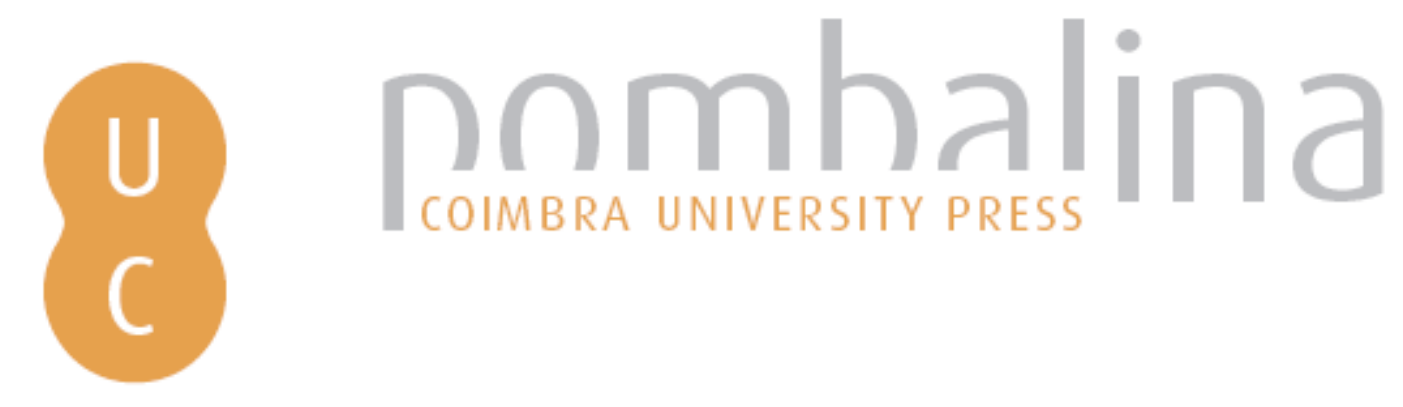

\title{
"Estados Unidos e Europa: entre parceria e isolacionismo": uma visão desde a Geografia
}
Autor(es):
Fernandes, João Luís J.
Publicado por: Imprensa da Universidade de Coimbra
URL
persistente:
URI:http://hdl.handle.net/10316.2/47310
DOI:
DOI:https://doi.org/10.14195/978-989-26-1849-4_19
Accessed : $\quad$ 26-Apr-2023 09:04:04

A navegação consulta e descarregamento dos títulos inseridos nas Bibliotecas Digitais UC Digitalis, UC Pombalina e UC Impactum, pressupõem a aceitação plena e sem reservas dos Termos e Condições de Uso destas Bibliotecas Digitais, disponíveis em https://digitalis.uc.pt/pt-pt/termos.

Conforme exposto nos referidos Termos e Condições de Uso, o descarregamento de títulos de acesso restrito requer uma licença válida de autorização devendo o utilizador aceder ao(s) documento(s) a partir de um endereço de IP da instituição detentora da supramencionada licença.

Ao utilizador é apenas permitido o descarregamento para uso pessoal, pelo que o emprego do(s) título(s) descarregado(s) para outro fim, designadamente comercial, carece de autorização do respetivo autor ou editor da obra.

Na medida em que todas as obras da UC Digitalis se encontram protegidas pelo Código do Direito de Autor e Direitos Conexos e demais legislação aplicável, toda a cópia, parcial ou total, deste documento, nos casos em que é legalmente admitida, deverá conter ou fazer-se acompanhar por este aviso.

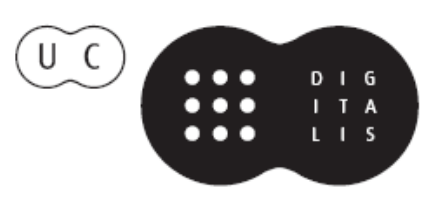


Euro-Atlântico:

Espaço de Diálogos

Isabel Maria Freitas Valente

Iranilson Buriti de Oliveira

(Coord)

\section{VISÕES \\ INTERDISCIPLINARES \\ DA EUROPA \\ E DO MUNDO:}

uma experiência de convergência

disciplinar em homenagem a

Maria Manuela Tavares Ribeiro

Alexandra Aragão

Isabel Maria Freitas Valente

Dulce Lopes

(org.)

Editora da Universidade Federal de Campina Grande

Imprensa da Universidade de Coimbra

2019 


\section{"ESTADOS UNIDOS E EUROPA: ENTRE PARCERIA E ISOLACIONISMO”, UMA VISÃO DESDE A GEOGRAFIA}

João Luís J. Fernandes

Entre o final do século XIX e 1954, terão passado por Ellis Island, ao largo de Manhattan, cerca de 12 milhões de imigrantes em direção aos EUA, provenientes de muitas regiões do mundo, em particular a Europa. Para aquela ilha-fronteira localizada na foz do Hudson River dirigemse agora turistas que, num exercício de memória, refazem em sentido inverso os caminhos dos antepassados. Depois de identificaram o nome do familiar no muro que evoca e patrimonializa aquele movimento migratório, estes turistas de celebração da identidade seguem para os lugares de origem e partida, em muitos casos outra ilha - a Irlanda.

Logo depois da II Guerra Mundial, está também documentada a chegada de viajantes norte-americanos ao continente europeu. Um turismo transatlântico movido por interesses políticos foi um meio de afirmação dos EUA na Europa e um instrumento de 'poder suave' (soft power) que estabilizou o território e o auxiliou na aproximação aos valores da democracia liberal.

Mas regressemos à Irlanda, mais uma vez a um território insular e a outro espaço de memória. Em Valentia Island, uma placa celebra um evento de 1858- a primeira mensagem de teleférico trocada entre os dois continentes. Como escreveu Stefan Zweig, este foi um dos grandes momentos da humanidade.

Façamos a viagem de volta à costa ocidental dos EUA, a cidades como New York ou New Bedford, às geografias de celebração do St. Patrick ou do "Dia de Portugal, de Camões e das Comunidades Portuguesas", com parades e manifestações de identidades de matriz europeia que aqui se territorializam.

Continuemos nos EUA, mais a sul, no Estado do Texas e numa cidade de Paris que parece evocar a capital francesa. Para além de uma geografia simbólica representada por um cineasta europeu (Wim Wenders), nesta anatopia parisiense encenou-se um geossímbolo, uma 
Torre Eiffel kitsch à qual se acrescentou um chapéu texano que coroa este ícone urbano estilizado.

Como nos mostra, na perspetiva das Relações Internacionais, o muito profundo e documentado texto de Miguel Rocha, a cooperação transatlântica, na sua vertente mais formal, tem passado por altos e baixos, com uma flutuação sensível que oscila ao sabor das opções políticas.

No entanto, as pontes entre as duas margens do Atlântico Norte estão para além da esfera institucional e política, foram traçadas por mobilidades que continuam a unir territórios que, nas novas conceções de demarcação geográfica, nem estão longe nem separados. Nas fronteiras multidimensionais que nos habituámos a ler a partir das problematizações de Adriano Moreira, nas quais aos limites políticos não correspondem os económicos, nem estes aos de segurança e aos culturais, a Europa e a América do Norte são territórios de proximidade e vizinhança. Mesmo numa leitura cartográfica mais plana, o Atlântico Norte não é um mero espaço de transição e viagem, é um território contínuo no qual países como Portugal confinam com os EUA e o Canadá, colocando, lado a lado, os limites das Zonas Económicas Exclusivas, das Plataformas Continentais, das Search and Rescue Regions (SRR) ou das Fly Information Regions (FIR), desconstruindo a perceção e os mapas mentais que consideram Espanha como a única vizinhança do Estado português.

Talvez estas cartografias de continuidade sejam uma garantia de confiança e uma das condições para a solidez do Atlântico Norte, por comparação com as incertezas e instabilidades que se notam mais a sul, no Atlântico Meridional, com margens mais turbulentas e fluxos difíceis de regular.

Não convém ignorar o potencial disruptivo das alterações climáticas e da deslocação de alguns centros gravitacionais de poder para o Pacífico. Não é possível desconsiderar o modo como o sistema internacional é hoje um complexo campo de interação entre atores estatais e não estatais. Apesar disso, aos olhos da Geografia Cultural e Política, entre escalas espaciais e temporais variadas, entre referenciais 
elásticos, flexíveis e porosos que vão oscilando ao ritmo das conjunturas políticas, existe uma base transatlântica sedimentada que perdura e faz do Atlântico um espaço geográfico de interdependências e influências múltiplas no qual Portugal, e um território como o Arquipélago dos Açores, desempenhará sempre um papel central.

O texto que Miguel Rocha nos apresenta é, por tudo isso, um estimulante objeto de reflexão que nos abre um vasto campo de debate sobre os diferentes níveis de proximidade e/ou afastamento entre territórios, que nos remetem para o sentido polissémico da distância, na qual a política formal será apenas um dos domínios a considerar. 